\title{
«For the Union Dead»: A Bostonian's Notes
}

By

Ruth Sherry

University of Trondheim

Robert Lowell's "For the Union Dead" is very much a poem of place, and in general the poem's imagery creates internally the significance of the specific landmarks in Boston which Lowell uses to carry his themes. Nevertheless, much of the material in the poem has special associations for Bostonians, associations which are perhaps not so readily apparent to others; these associations both enrich one's understanding of the poem and in some cases help to explain why Lowell has chosen a particular vehicle for his poetic statement.

The "bronze weathervane cod" on the derelict South Boston Aquarium, which has "lost half its scales," fits generally into the pattern of the poem's concern for the loss of continuity, here the continuity of organic life. The evolution of the fish from freedom to captivity to devitalization to ultimate disintegration is conveyed partly by the bronze cod's loss of its scales. What may be less obvious to the general reader is that in Boston, indeed in Massachusetts generally, the cod is also intimately associated in the public mind with the existence and identity of the state. The significance of the cod for the early economy of the colony is a familiar fact, and the name given to Massachusetts' most striking geographical feature, "Cape Cod," reflects the cod's importance in the life of the early settlers.

The cod is not an "official" symbol of the state; nevertheless, it is so accepted and time-honored a symbol that the most prominent feature of the main legislative chamber in Bulfinch's State House which Lowell later draws into his poem - is a great golden cod which hangs above the legislators as they conduct their deliberations. "The sacred cod in the State House" is the highlight of tours of the 
building and is much photographed; it is familiar to almost every citizen. By means of the image of the cod, then, Lowell links the theme of organic deterioration with the poem's political theme; the loss of scales on the bronze weathervane cod is ominous of the decline of public integrity.

Most of the geographical imagery of the poem is drawn from a central area in Boston which is one of the oldest settled and one rich with historical associations. This area might roughly be defined as that of the Boston Common and the Public Garden, the streets bordering these, and the areas immediately adjacent. As the poem makes more or less clear, the State House faces Boston Common across the Common's northern boundary, Beacon Street. On the perimeter of the Common, facing the State House, is the memorial to Robert Gould Shaw and his Negro regiment.

The State House sits at the summit of Beacon Hill, which extends to the north and west. Beacon Hill was, and to a large extent still is, the traditional home of the Boston aristocracy, the "Brahmins" from whom Lowell himself descended, his family immortalized if in no other way - in the notorious gibe:

This is dear old Boston

The home of the bean and the cod

Where the Lowells speak only to Cabots

And the Cabots speak only to God. ${ }^{1}$

Lowell's associations with this social group and this neighbourhood are of course facts familiar to even the most casual readers of his poems, which frequently draw upon private, family, and local history and employ clearly identified geographical settings, as for example in his piece about his Beacon Hill childhood, "91 Revere Street." The Boston Brahmins as a social group with a distinctive intellectual and cultural tradition are likewise in need of no introduction here; positive and negative aspects of this group's history and activities have been amply described by others.

What is relevant for the poem, however, is that one of the more attractive aspects of the Brahmin tradition is the continuing thread of a sense of public responsibility, in particular - although not only in relation to the situation of American Negroes. Robert Gould Shaw (whose sister married one of Lowell's ancestors) came from one of the many aristocratic Boston families profoundly committed to the Abolitionist cause. The tendency did not die out with the Civil War; four years after this poem was written, the elderly mother of 
the then-Governor of Massachusetts, Endicott Peabody (whose name in itself is a distillation of the Massachusetts aristocracy), was jailed in Florida for participating in a Civil Rights demonstration. Lowell's poem might be seen as his own contribution to the cause, an indication of the same public conscience which later made him a prominent, and early, opponent of the Vietnam war.

Lowell uses the Boston Common as a central image in the poem. He does not mention the Public Garden, but, for reasons which will appear, the two are generally linked, if only as opposites, in the public mind. Boston Common and the Public Garden appear, on a map, as a continuous park, divided only notionally by Charles Street. In history and in atmosphere, however, they are quite different. Boston Common, as its name suggests, was originally the public grazing ground; it is a "common" in the English sense and is the oldest public park in the United States, the subject of a statute establishing its status as early as 1640 . The Common is still comparatively rough and humpy; sheep and deer graze at Christmas time as part of an open-air Christmas display, and cows can occasionally be seen in the spring as part of a dairy exhibition. The Public Garden, which lies on filled-in land, was not made into a park until 1859; by contrast with the Common it is formal, carefully planted and manicured, its flower beds and pedal-propelled Swan Boats the city's decorous delights.

The physical contrasts between the two parks are, for our purposes, interesting largely as reflections of their formal status, which is something of a legal anomaly. The Public Garden, like all the other parks in Boston, belongs to the City of Boston, but the Common, by virtue of the original statute governing it, belongs to the People of Boston. This is a distinction which may sound quibbling, but it has been tested over and over again in the courts, and has real practical consequences. No activity, not in itself illegal, can be forbidden on the Common; one can do there whatever one can do in one's own back yard. Vagabonds and other free spirits are hustled out of the Public Garden at night, but sleep undisturbed by the police across the way on the Common. Boston schoolchildren learn a little rhyme which dramatizes the point:

The Common belongs to the People;

The People - that means me!

I can sleep on the lawn

From twilight to dawn.

I can watch a ball game, free. 
building and is much photographed; it is familiar to almost every citizen. By means of the image of the cod, then, Lowell links the theme of organic deterioration with the poem's political theme; the loss of scales on the bronze weathervane cod is ominous of the decline of public integrity.

Most of the geographical imagery of the poem is drawn from a central area in Boston which is one of the oldest settled and one rich with historical associations. This area might roughly be defined as that of the Boston Common and the Public Garden, the streets bordering these, and the areas immediately adjacent. As the poem makes more or less clear, the State House faces Boston Common across the Common's northern boundary, Beacon Street. On the perimeter of the Common, facing the State House, is the memorial to Robert Gould Shaw and his Negro regiment.

The State House sits at the summit of Beacon Hill, which extends to the north and west. Beacon Hill was, and to a large extent still is, the traditional home of the Boston aristocracy, the "Brahmins" from whom Lowell himself descended, his family immortalized if in no other way - in the notorious gibe:

This is dear old Boston

The home of the bean and the cod

Where the Lowells speak only to Cabots

And the Gabots speak only to God. ${ }^{1}$

Lowell's associations with this social group and this neighbourhood are of course facts familiar to even the most casual readers of his poems, which frequently draw upon private, family, and local history and employ clearly identified geographical settings, as for example in his piece about his Beacon Hill childhood, "91 Revere Street." The Boston Brahmins as a social group with a distinctive intellectual and cultural tradition are likewise in need of no introduction here; positive and negative aspects of this group's history and activities have been amply described by others.

What is relevant for the poem, however, is that one of the more attractive aspects of the Brahmin tradition is the continuing thread of a sense of public responsibility, in particular - although not only in relation to the situation of American Negroes. Robert Gould Shaw (whose sister married one of Lowell's ancestors) came from one of the many aristocratic Boston families profoundly committed to the Abolitionist cause. The tendency did not die out with the Givil War; four years after this poem was written, the elderly mother of 
the then-Governor of Massachusetts, Endicott Peabody (whose name in itself is a distillation of the Massachusetts aristocracy), was jailed in Florida for participating in a Civil Rights demonstration. Lowell's poem might be seen as his own contribution to the cause, an indication of the same public conscience which later made him a prominent, and early, opponent of the Vietnam war.

Lowell uses the Boston Common as a central image in the poem. He does not mention the Public Garden, but, for reasons which will appear, the two are generally linked, if only as opposites, in the public mind. Boston Common and the Public Garden appear, on a map, as a continuous park, divided only notionally by Gharles Street. In history and in atmosphere, however, they are quite different. Boston Common, as its name suggests, was originally the public grazing ground; it is a "common" in the English sense and is the oldest public park in the United States, the subject of a statute establishing its status as early as 1640 . The Common is still comparatively rough and humpy; sheep and deer graze at Christmas time as part of an open-air Christmas display, and cows can occasionally be seen in the spring as part of a dairy exhibition. The Public Garden, which lies on filled-in land, was not made into a park until 1859; by contrast with the Common it is formal, carefully planted and manicured, its flower beds and pedal-propelled Swan Boats the city's decorous delights.

The physical contrasts between the two parks are, for our purposes, interesting largely as reflections of their formal status, which is something of a legal anomaly. The Public Garden, like all the other parks in Boston, belongs to the City of Boston, but the Common, by virtue of the original statute governing it, belongs to the People of Boston. This is a distinction which may sound quibbling, but it has been tested over and over again in the courts, and has real practical consequences. No activity, not in itself illegal, can be forbidden on the Common; one can do there whatever one can do in one's own back yard. Vagabonds and other free spirits are hustled out of the Public Garden at night, but sleep undisturbed by the police across the way on the Common. Boston schoolchildren learn a little rhyme which dramatizes the point:

The Common belongs to the People;

The People - that means me!

I can sleep on the lawn

From twilight to dawn.

I can watch a ball game, free. 
The Common belongs to the People;

The People - that means You!

You can stand on a chair

And find fault with the Mayor,

For nobody cares what you do.

BUT

The Garden belongs to the City;

The City - that isn't me!

I'm restricted by signs

And threatened with fines,

And even the Swan Boats aren't free.

The Garden belongs to the City;

The City - that isn't You!

You're forbidden to wade

In the pond that they made,

You'd be stopped if you took off one shoe. ${ }^{2}$

Attempts to alter the status of the Common, to sell pieces of it, build permanent buildings on it, or otherwise turn it to uses other than its traditional ones, have always met with profound opposition. The city's proposal to build a parking garage under the Common a project mooted for years and finally realized at the beginning of the 1960 's - produced the most heated struggle of such a kind in recent times. Many regarded the building of the garage as a patent. infringement of the people's rights over the Common, and legal challenges to the project by citizens' groups - in which Beacon Hill Brahmins were heavily represented - occupied the courts for years. The courts eventually determined on a species of compromise: no land for the project was to be taken from the Common itself; the entrance to the garage was created out of one of the bordering streets. The surface of the Common was to be restored to its. original contours after the construction was finished, and the only alteration allowed in the Common's appearance was the provision for a couple of inconspicuous shafts rising above stairs leading down to the garage below.

Nevertheless, many remained outraged, and saw the decision as. a dismissal of the rights of individual citizens, rights previously held sacred. To many, the building of the garage virtually represented. the acceptance of totalitarianism, the absolute authority of the state. It is in this atmosphere, with the construction going ahead, that Lowell's poem took shape. Ground for the garage was broken on March 4th, 1960, an event the poem records. Lowell completed 
The Common belongs to the People;

The People - that means You!

You can stand on a chair

And find fault with the Mayor,

For nobody cares what you do.

BUT

The Garden belongs to the Gity;

The City - that isn't me!

I'm restricted by signs

And threatened with fines,

And even the Swan Boats aren't free.

The Garden belongs to the City;

The City - that isn't You!

You're forbidden to wade

In the pond that they made,

You'd be stopped if you took off one shoe. ${ }^{2}$

Attempts to alter the status of the Common, to sell pieces of it, build permanent buildings on it, or otherwise turn it to uses other than its traditional ones, have always met with profound opposition. The city's proposal to build a parking garage under the Common a project mooted for years and finally realized at the beginning of: the 1960's - produced the most heated struggle of such a kind in recent times. Many regarded the building of the garage as a patent infringement of the people's rights over the Common, and legal challenges to the project by citizens' groups - in which Beacon Hill Brahmins were heavily represented - occupied the courts for years. The courts eventually determined on a species of compromise: no land for the project was to be taken from the Common itself; the entrance to the garage was created out of one of the bordering streets. The surface of the Common was to be restored to its. original contours after the construction was finished, and the only alteration allowed in the Common's appearance was the provision for a couple of inconspicuous shafts rising above stairs leading down to the garage below.

Nevertheless, many remained outraged, and saw the decision as. a dismissal of the rights of individual citizens, rights previously held sacred. To many, the building of the garage virtually represented. the acceptance of totalitarianism, the absolute authority of the state. It is in this atmosphere, with the construction going ahead, that Lowell's poem took shape. Ground for the garage was broken on March 4th, 1960, an event the poem records. Lowell completed. 
the poem in time to read it at the Boston Arts Festival in the Public Garden on June 5 th of the same year. ${ }^{3}$ Lowell seems to have begun writing a poem about Colonel Shaw somewhat earlier than this. In the same period, in the South, the first attempts at the integration of schools were taking place, in the wake of the Supreme Court decision of 1954 which outlawed legalized segregation; the spectacle of small black children being led past screaming and spitting white mobs became part of the nightly television news.

In the completed poem as we have it, Lowell links these events: the violation of the Common, in Boston, is a public repudiation of the values of equality, community, and individual right, just as the opposition to school desegregation is, in the South. The moral voice set up against these violations is that of Shaw's father, asserting the equality of the Negro soldiers and his dead son. Thus the construction of the underground garage shakes both the State House and the Shaw monument; the inherited values represented by both are threatened. If even Boston betrays its heritage, what hope is there for the nation?

Boylston Street, where the Mosler Safe Company had its showrooms when the poem was written, runs along the south side of the Common and the Public Garden and leads out to a newer part of Boston. ${ }^{4}$ The window display gives more evidence of the deterioration of public morality, the indifference of the state to the value of individual life. Lowell, it will be remembered, was imprisoned as a conscientious objector during World War II.

Lowell links this political theme with an evolutionary one. The decline of public values is paralleled with human loss of contract with, and identity with, the animal world, whereas the integration of these two worlds is represented partly by the animal imagery associated with Colonel Shaw. Organic life is being replaced by machines, beginning their own terrifying evolution. Thus Lowell carries the theme out beyond its immediate relevance for Boston and the United States: in more than one way the poem is an elegy for "the union dead." It does not only mourn those who, like Shaw, died on the Union side in the Civil War; it also mourns the death of the union between citizens and res publica, between human and other forms of life.

It has been widely acknowledged that this poem is one of the most satisfying products of Lowell's gift for perceiving in local, even parochial, history, a stimulus to the poetic imagination and a spur to the ethical impulse. The garage under Boston Common is now 
an accepted part of the city's life, and the controversy which surrounded its construction is now largely forgotten. The Shaw memorial is intact, there is a new Aquarium, and the Mosler Safe Company no longer occupies premises on Boylston Street. Yet the poem is not outdated, nor is it merely a quaint Boston curiosity. By virtue of Lowell's synthesizing vision, the historical moment always directs our attention forward as well as back. The Boston Common controversy may be a thing of the past, but the issues of which it is an emblem have followed Boston, America, and indeed much of the modern world. They continue to point toward a yet unimagined future.

\section{NOTES}

1 A toast given by John Collins Bossidy in 1910 at the Alumni Dinner of Holy Cross (a Roman Catholic college.) It is said to be based on a similar antiBrahmin-rhyme toast offered by a Westerner at the 25th Alumni Dinner of the Harvard Class of 1880. (Bartlett's Familiar Quotations.)

2 The rhyme is anonymous. I have taken the text of it from George F. Weston, Jr., Boston Ways: High, By, and Folk (Boston: Beacon Press, 1974), p. 128. Weston gives a good brief account of the history of the two parks.

3 The poem was first published in the paperback edition of Life Studies in the autumn of 1960. As Life Studies was first published (hardbound) in the previous year, an incorrect date of 1959 is sometimes given for the poem. It was originally titled "Colonel Shaw and the Massachusetts 54th," but was given its present title in subsequent printings.

4 For some reason the name is given as "Boyleston Street" in some editions of the poem. 